\title{
Role Of The Center For Abandonment Of Property Law To Safeguard Assets Subsidiaries Who Still Under Age
}

\author{
Agustina Suryaningtyas ${ }^{1}$
}

\begin{abstract}
For those who are not competent to act in a legal act such as minors and people who are in wardship, in legal actions both in and out of court must be represented by a person appointed by the trial judge, that is able to parent, guardian or sycophants. Duties as guardian or caretaker are very spacious and are at risk for problems associated with wealth, so that the necessary role of an institution or agency in charge of overseeing the implementation of trusteeship and guardianship. Parents, family and society are responsible for protecting and maintaining human rights in conformity with the obligations imposed by law. Similarly, in view of the protection of children, the state and the government is responsible for providing facilities and accessibility for children, especially in ensuring optimal growth and development and focused. Heritage Hall is one of the Technical Unit within the Ministry of Justice and Human Rights of the Republic of Indonesia has the duty and obligation to protect human rights. Especially in the field of personal right person for Judge's decision can not run their own interests by the legislation in force. Ranking Universal Heritage as guardian watchdog is still needed, and it is possible to apply to all Indonesian citizens, thus Orphan peningalan can act in the national interest to provide legal protection for children who are under guardianship committed by Indonesian.
\end{abstract}

Keywords: Heritage Office; Minors; Guardianship.

\section{Introduction}

Since birth, the human subject is recognized as a person or private law which has the authority entitled to, namely the authority as a supporter of the rights and obligations of civil law. With regard to inheritance rights, Article 2 of the Code of Civil Law mentions human position as a supporter of the rights and obligations came into effect still in the womb. ${ }^{2}$ Man by law recognized as persons with rights and obligations as a legal subject or person. ${ }^{3}$

Any legal person may act alone when menganggab legal person is competent, capable or worthy act in legal actions. In Article 1329 of the Civil Code ${ }^{4}$ Competent legal subjects legal act can be declared legally competent if the law says so. As for the subject of legal persons legally declared incompetent to do the law is a minor or minors, those under guardianship, those girls who set the law, all persons to whom the law has prohibited certain legal actions.

For those who are not competent to act in a legal act such as minors and people who are in wardship, in legal actions both in and out of court must be represented by a person appointed by the trial judge, that is able to parent, guardian or sycophants.

\footnotetext{
${ }^{1}$ Student of Masters (S2) of Law Faculty of Law Unissula Semarang Email: suryastyas@gmail.com

${ }^{2}$ The Book of the Law of Civil Law Article 2

${ }^{3}$ Sudikno Mertokusumo 1996 Mengenal Hukum Suatu Pengantar Liberty Yogyakarta p. 60.

${ }^{4}$ The Book of the Law of Civil Law.
} 
Duties as guardian or caretaker are very spacious and are at risk for problems associated with wealth, so that the necessary role of an institution or agency in charge of overseeing the implementation of trusteeship and guardianship.

Children are a gift of God and trust in God Almighty, that we will always be because of her inherent dignity, dignity, and human rights that must be upheld. Children's rights are part of human rights contained in the Constitution of the Republic of Indonesia Of 1945 and the United Nations Convention on the Rights of the Child. From the life of the nation, children are the future of the nation and future generations the ideals of the nation, so that every child has the right to live, grow, and develop, participate and be protected from violence and discrimination and civil rights and freedoms.

Although Act No. 35 of 2014 on the Amendment of Act No. 23 of 2002 on Child Protection in conjunction with Act No. 39 of 1999 on Human Rights have included about children's rights, implementation of the obligations and responsibilities of parents, families, communities, government, and the state to provide protection to the child still needs a law on the protection of children as the juridical basis for the implementation of the obligations and responsibilities. Thus, parents, family, and community are responsible for maintaining and preserving these rights in accordance with the obligations imposed by law. Similarly, in view of the protection of children, the state and the government is responsible for providing facilities and accessibility for children,

Heritage Hall is one of the Technical Unit within the Ministry of Justice and Human Rights of the Republic of Indonesia has the duty and obligation to protect human rights. especially in the field of personal right person for Judge's decision can not run their own interests by the legislation in force.

\section{Research Methods}

Role of Heritage Research Center for the Legal Protection Efforts Against Child Assets Still Under The Age According to the Civil Code and Act No. 35 of 2014 on the Amendment of Act No. 23 of 2002 on Child Protection is performed with empirical juridical approach. Juridical empirical approach was chosen because the object of study is the law or the rules of law and the data used is empirical data on the legal protection of the property of minors and the role of the Universal Heritage.

The method is empirical juridical approach method or procedure that is used to solve problems in research by examining the secondary data prior to then proceed to conduct research on primary data in the field. ${ }^{5}$

\section{Results And Discussion}

Guardianship is the supervision of children under age who are not under the authority of the parents and the management of objects or property of the child as stipulated by law. ${ }^{6}$ According to article 331 of the Civil Code, in every guardianship there is only one

\footnotetext{
${ }^{5}$ Soerjono Soekanto 1986. Pengantar Penelitian Hukum Jakarta : UI Press p. 52

${ }^{6}$ Prof. Subekti SH 1994 Pokok-pokok Hukum Perdata PT. Intermasa Jakarta p.44
} 
guardian, except in the case of a trust committed by a mother when they married, her husband would become a saint as well.

Definition of guardianship according to the draft Civil Code (Burgerlijk Wetboek) is the management of children under age who are not under the authority of parents and take care of the property or assets of the child in accordance with the law.

Universal Heritage is an institution or state agency that was originally established by the government kolonia turkey, but after the Proclamation of Independence on 17 August 1945 under Article II of the Transitional Provisions of the Law of the Republic of Indonesia Of 1945 is recognized as an institution or state agency in the field of civil law, mewakiili duty and take care of the interests of the people because of the law or a court decision can not run their own interests by the legislation in force. Function Hall Heritage is performing in terms of managementTrusts (voogdij), forgiveness (Curatele), Absence (Afwezigheid) The estate of unmanageable (onbeheerde Nalatenschappen), Bankruptcy, Bookkeeping and Registration of wills and, to make a declaration of inheritance.

One of Duty and Function of the Universal Heritage under Article 3 of the Decree of the Minister of Justice of the Republic of Indonesia Number M.01.PR.07.01-80 1980 dated 19 June 1980 regarding Organization and Work Institute for Heritage, in particular Article 3 of the Universal Heritage has the function of performing troubleshooting and Assisted Living Trusts. Then it is also stipulated in Article 449 and 366 Civil Code as amended. Act No.23 of 2002 on the Protection of Children, as amended by Act No.35 of 2014.

The foregoing shows that the rights and duties of man as a subject of law equal before the law. Human (people) who are in wardship and guardianship, they are categorized by the Law of the incompetent acts of law. Therefore we need an institution that oversees their rights, especially in wealth to those who do not speak act of law is not harmed, the Indonesian Institute is known as the Universal Heritage.

Heritage Hall is a state institution or agency legal services have duties and obligations to protect human rights, especially in the field of personal right person for Judge's decision can not run their own interests by the legislation in force.

Heritage Hall was originally an institution established by the Dutch colonial government. Legislation on Heritage Hall is a part of family law contained in Book I of the Civil Code (Burgerlijk Wetboek) and other regulatory rules that most of the products of civil law heritage Dutch colonial government.

In effect the service of the Universal Heritage is very precious ?? Representing Interests And Manage People (Legal) The ruling Justice For Legal Or Not Running Alone importance Pursuant to Rule Legislation Applicable ??. ${ }^{7}$

Complete the task Hall Heritage is to supervise in terms of the Trust, Assisted Living, managing assets of which there is no power, managing assets of persons (legal) specified is not present, open and register a last will of the testator, the creation of the Certificate of Inheritance Rights and Curator in Bankruptcy.

If viewed juridical most of the legislation that the legal basis the duties and functions of the House of Heritage, including the Book of the Law of Civil Law and the Ordinance

\footnotetext{
7 The Minister of Justice of the Republic of Indonesia dated 19 June 1980 No. 1980 About M.01.PR.07.01-80 Organization and Work Institute for Heritage article 2
} 
of the Instruction Center of Heritage in Indonesia dating from before independence which is a product of the colonial, and just happen against certain population groups, such as the Indonesian citizen Foreign descent and Eastern Europe. These regulations is no longer perceived by the present situation, because it is not in line with the mandate of Pancasila and the Constitution of the Republic of Indonesia Of 1945, therefore needs to be adjusted through legal reform.

Duties and functions of Heritage as stipulated in the Law of Civil Law is intended for the European and Foreign East, can be said to have a role and scope is quite wide, but its presence is felt not strong enough. This could happen because of his role or less socialized duties and functions, and the legal basis for setting the duties and functions of the House of Heritage is lagging and inadequate.

According to the Book of the Law of Civil Law, Center for Heritage is the government agency tasked with overseeing the implementation of the Guardianship and authority and Assisted Living. Heritage Hall was established by Resolution of the GovernorGeneral Pieter de Carpentier on October 1, 1624 and is domiciled in Jakarta. At first Universal Heritage was established with the function to manage the interests of law and tackling the problems of citizens of the VOC (Dutch) in Indonesia who died of illness, accident or because of war, and left a legacy that fell to the children who are minors (guardianship) and inheritance that does not exist manager

Since the enactment of Act No. 1 of 1974 which is one of the reform of civil law in Indonesia, most of the rules in the Civil Code is no longer valid. Civil Code applies to those who submit to the general civil law. As for the indigenous groups do not apply. Heritage Center of the functions and role of the national interest.

As a result there is a lot of the general public who know the Universal Heritage as a national agency or agencies that have a role in the guardianship process, in terms of managing and protecting the interests of a minor child who is not under the authority of parents.

In article 50 to article 54 of Act No. 1 in 1974, has been set on the guardianship of children. But in these articles are not listed on the role of the House of Heritage and other agencies as guardian watchdog. Though the role of guardian of supervisor is needed in the guardianship process, especially to protect the interests of children on its assets.

According to Article 66 of Act No. 1 of 1974, all the things that have not been regulated in Act No. 1 of 1974 but has been regulated in the other, then the other regulations remain valid. This is in accordance with the mandate of Article 2 of the Transitional Provisions of the 1945 Constitution, which states that any state or regulatory body for not regulating the otherwise valid.

Based on this, the task peningalan Orphan as Supervising Guardian and regulations of the Civil Code and Stb. No. 1972166 which set is still valid in civil law system of Indonesia, the reason is not regulated in others.

The general public needs to know and recognize the importance of Orphan peningalan duty as guardian guardianship oversight in the process, so as to prevent a legal vacuum in terms of trust and create legal certainty for the benefit of children under age.

In connection with the appointment of a guardian by a court decision, in article 35 of Act No. 23 of 2002 on the protection of the child, if the court has not established who 
the guardian of the child, then the child's assets can be managed by the Center for Heritage Administration or other agency that has authority to do so. In this case the Universal Heritage to act as guardian watchdog.

Ranking Universal Heritage as guardian watchdog is still needed, and it is possible to apply to all Indonesian citizens, thus Orphan peningalan can act in the national interest to provide legal protection for children who are under guardianship committed by Indonesian.

\section{Conclusion}

- Legislation on Heritage Hall that most still use the civil law of the Netherlands, is not in keeping with the law. Shades of discrimination that groups of citizens into classes is an act that violates human rights.

- In addition, conflicts of regulations on the implementation of the tasks Heritage Center with the laws and regulations of the newborn, resulting in the execution of tasks Heritage Hall was not optimal and has many obstacles.

- Based on the above and in the framework of efforts to implement legal reforms, have prepared the Draft Law on Heritage Hall. The draft law must benefit and be able to provide protection of the interests and needs based on a sense of justice in society so that its presence becomes a living and effective laws to be obeyed and implemented seriously by society.

- Bill Heritage Center is expected to serve as guidelines for the Universal Heritage in performing their duties or terayominya and protection of Human Rights, particularly by law and a court decision dianggab not capable of running its own interests by the legislation in force.

\section{Bibliography}

[1] C.S.T. Kansil S.H. 2003 Pengantar IImu Hukum dan Tata Hukum Indonesia Balai Pustaka Jakarta.

[2] HMN. Purwosutjipto 1997 Pengertian Pokok Hukum Dagang Indonesia Penerbit Jembatan Jakarta

[3] J. Satrio 1999 Hukum Pribadi: Bagian I Persoon Alamiah Citra Aditya Bakti Bandung.

[4] Munir Fuady SH. MM. LL. M. 1998 Hukum Pailit Penerbit PT. Citra Aditya Bakti Bandung.

[5] P.N.H. Simanjuntak 1999 Pokok-pokok Hukum Perdata Indonesia Djambatan Jakarta.

[6] R. Subekti 1979 Pokok-pokok Hukum Perdata Intermasa Jakarta.

[7] Rachmadi Usman S.H. 2005 Aspek-aspek Hukum Perorangan \& Kekeluargaan di Indonesia Sinar Grafika Jakarta.

[8] Republic of Indonesia 1975 the Association of Legislation House of Heritage Directorate General of Law and Legislation Department of Justice Jakarta

[9] Republic of Indonesia Bankruptcy Act (Faillisement Verodering) 1905 LN 217 jo. Stb. 1906 \# 348, 
[10] Republik Indonesia 1975 Himpunan Peraturan Perundang-undangan Balai Harta Peninggalan Direktorat Jenderal Hukum dan Perundang-undangan Departemen Kehakiman Jakarta

[11] Satjipto Rahardjo 1979 Hukum dan Perubahan Sosial Alumni Bandung.

[12] Sudarsono SH 1991 Hukum Kekeluargaan Nasional Rineka Cipta Jakarta.

[13] Sudikno Mertokusumo 1996 Mengenal Hukum Suatu Pengantar Liberty Yogyakarta.

[14] Sunarto Ady Wibowo S.H. 2003 Hak dan Kewajiban Orangtua dan Anak Menurut K.U.H.Perdata dan Undang-undang No. 1 Tahun 1974 Universitas Sumatera Utara: Fakultas Hukum. 